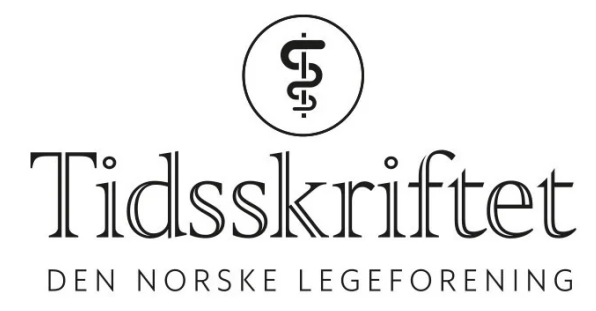

\title{
Epidemi med poliomyelitt i 1868
}

TIDLIGERE I TIDSSKRIFTET

JULIE DIDRIKSEN

julie.didriksen@tidsskriftet.no

Tidsskriftet

I Tidsskriftets utgave 17/1999 kunne vi lese en artikkel om den første gangen en epidemi med poliomyelitt ble beskrevet i Europa. Det var norske Andreas Christian Bull som beskrev utbruddet i sin Medicinalberetning fra Søndre Odalen for året 1868, og dette var hans første år som allmennpraktiserende lege. I artikkelen fortelles det at Bulls beretning var relativt ukjent før nevrolog og professor Christopher Leegaard (1851-1921) fant den og gjorde en innsats for at den ikke skulle forsvinne i glemmeboken igjen. Du kan lese Bulls beskrivelse av utbruddet under (Tidsskr Nor Lægeforen 1999; 119: 2574).

Poliomyelitt i Odalen i 1868

Torkel Bache, Utvalget for Gammeldoktoren, Hedmark lægeforening 


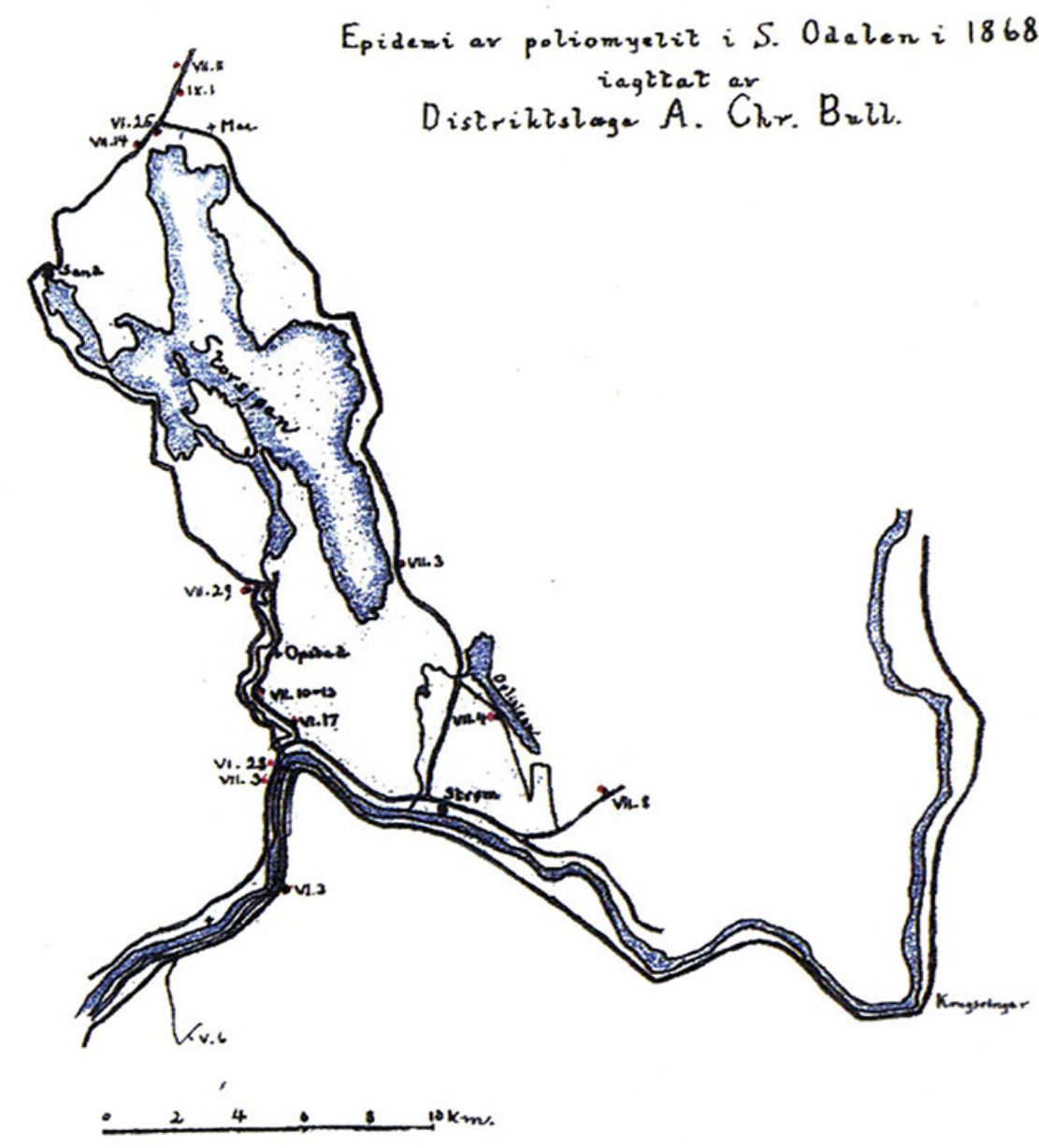

\section{MENINGITIS SPINALIS ACUTA}

«For Meningitis spinalis acuta behandledes 14, hvoraf 5 døde. Da et saavidt stort Antal blev angrepet av denne, visselig sjeldne Sygdom, vil jeg tillade mig at omtale den noget udførligere. Sygdommen begyndte med Feber, der dog hos de fleste var ganske let, derpaa indfandt der sig stikkende flugtende Smerter hist og her i de forskjellige Led og Lemmer samt Ryggen, og i nogle Tilfælde fandtes tillige mer eller mindre utbredt $\emptyset$ mfiendtlighet for Tryk langs Columna vertebralis, undertiden alene i Cervicalregionen, undertiden kun i det nederste af Dorsalregionen.

\section{«Det nceste Phcenomen var Parese eller i enkelte Tilfcelde fuldstcendig}

\section{Paralyse enten af et eller i Regelen afflere Lemmer»}

Det næste Phænomen var Parese eller i enkelte Tilfælde fuldstændig Paralyse enten af et eller i Regelen af flere Lemmer, indtrædende fra 3 til 4 à 5 Dager efter Sygdommens Udbrud; i et Tilfælde var det begge Underekstremiteterne, der lammedes, i Regelen var det et Ben og en Arm, dels paa samme Side dels krydsvis, i enkelte Tilfælde var det kun et Lem, ialfald hvor Paresen blev mere stationær, thi en ganske kortvarig og høist ubetydelig Parese af et andet Lem kunde som oftest paavises at have gaatt i Forveien. Undertiden fandtes ogsaa Parese af Nakkemusklene paa en eller begge Sider. Der var intetsomhelst Tegn til en samtidig Affection af Cerebrum, lidt Hovedpine, lidt Svindel og en sjelden Gang Brækning, var rigtignok tilstede hos nogle men maatte nærmest udledes af Feberen. Mærkeligt var, at der aldri i et eneste Tilfælde indfant sig Kramper, og ikke heller var nogen Anæstesi. Urinladningen bestandig normal paa en Undtagelse nær, hvor der var Retentio urinae; Storudtømmelsen ligeledes normal, var der lidt Obstructio blev den av kort Varighet. 
Efterat Sygdommen havde varet 4-5 Dage, indtraadte der en Vending, enten utbredte Paralysen sig videre, strakte sig omsider til Respirationsorganerne, og Døden paafulgte under lige til det sidste vedligeholdt fuld Bevidsthed, efterat Sygdommen i det hele neppe havde varet en Uge, - eller ogsaa forsvant alle Phænomen av Feber temmelig hurtig, i Regelen tillige Æmfiendligheden i Ryggen samt Smerterne, og med Undtagelse af den til intetgjorte eller svekkede Brug af et eller flere Lemmer begyndte de Syge forresten at komme sig temmelig snart. Paralysen ble for de flestes Vedkommende mindre og mindre udtalt og blev som oftest kun en Parese, og medens Lammelsen i Begynnelsen var ubtredt til alle et Lems Muskler, indskrænkedes Paresen senere kun til enkelte, saa at der opstod Contractur ved de ikke lammede Musklers Overmagt. Alle de 9, der overlevde Sygdommen er nu paa Benene, og de 6 er blevne betydelig bedre udover Vinteren, 3 kunne derimot kun gaa ved Hjælp av Krykker.»

Publisert: 19. april 2021. Tidsskr Nor Legeforen. DOI: 10.4045/tidsskr.21.0188

(C) Tidsskrift for Den norske legeforening 2023. Lastet ned fra tidsskriftet.no 26. april 2023. 